\title{
Uncertainties regarding the right to labour
}

\section{Opinion}

If two conflicting treaties address the same subject matter and are ratified by the same States, according to the Vienna Convention on the Law of Treaty (VCLT) Article 59, the latter treaty trumps the former treaty. 'The evolving nature of multi-lateral treaties does not leave them frozen in time', even if the International Covenant on Civil and Political Rights (ICCPR) that combined rights provisions with duty elements and that entered into force in March of 1976 followed the International Covenant on Economic, Social and Cultural Rights (ICESCR) with pure labour rights, which entered into force in January of the same year. Consequently, it is not possible to effectively resolve rights conflicts between two types of treaties - as in the case of conflict over Reform through Labour (RTL) - by applying the rule of labourbased subject matter. In the alternative, requirements of content might be applied to resolve conflicts over labour rights. In my opinion, however, the content rule is equally unhelpful in resolving rights conflicts in a fair and predictable manner, as may be demonstrated by the following major international human rights instruments that have labour rights as the subject or content.

In the field of international labour law, as one category of international law, various international and regional human rights instruments have been adopted to protect people's freedom to employment of their own choice and the right to fair working conditions and treatment. Such instruments feature a title regarding or focus on labour or rights. These rights and freedoms have been enforced by the introduction of compulsory provisions to which State parties should adhere. The United Nations (UN), European Commission, Organisation of American States and Organisation of African Unity have, over a long period, actively been engaged in the process of establishing standards to protect the right to labour and prohibition of forced labour. Both of these standards appear to be basic principles of international labour provisions, with respect to content, at the core of human rights protections for labourers.

Titled with 'rights' in general, the Universal Declaration of Human Rights (UDHR) in 1948, the American Declaration on the Rights and Duties of Man in 1948 and the African Charter of Human and People's Rights in 1981 all specify the right to work and prohibit forced labour as subjects of rights. The ICESCR in 1966 and the European Social Charter revised in 1996 also guarantee the right to work in addition to rights concerning pay, working conditions, rest and leisure that apply equally to forced labourers. In 1957, the Supplementary Convention on the Abolition of Slavery, the Slave Trade, and Institutions and Practices Similar to Slavery adopted the approach of simply referring to instruments regarding forced or compulsory labour in its Preamble to emphasise the right to labour in general. Conversely, the ICCPR, the European Convention for the Protection of Human Rights and Fundamental Freedoms and the American Convention on Human Rights expressly prohibited forced labour, respectively in 1966, 1953 and 1973; they list the relevant exceptions in their provisions. Focusing on labour rights, the International Convention on the Protection of the Rights of All Migrant Workers and Members of Their Families, effective in 2003, also explicitly prohibits such labour, with certain exceptions, emphasising the right to labour and excluding
Volume 3 Issue 5 - 2019

\author{
Na JIANG,' Yue WANG ${ }^{2}$ \\ 'Beijing Normal University, China \\ ${ }^{2}$ LLM candidate, Beijing Normal University, China \\ Correspondence: Na JIANG, Beijing Normal University, \\ 100875, China, Email na.jiang@bnu.edu.cn \\ Received: June 17,2019 | Published: September 17, 2019
}

China's constitutional duty to labour. Additionally, the Convention concerning Forced or Compulsory Labour, effective in 1932, and the Abolition of Forced Labour Convention, effective in 1959, indicate first that forced labour should be prohibited to protect the right to labour and, second, that such limits should act "as a model for most general human rights treaties". These instruments appear not to cover all relevant obligations of State parties under international labour law. Although this silence does not mean that no duty to labour exists, there is also no reason that such a duty should not be excluded, especially when that duty allows States to "compel old, sick women to work 70 hours per week for several months without compensation" "in the case of a natural calamity". Even if a duty to labour does exist, any form of forced labour must meet minimum legal standards for labour and social welfare, such as prohibiting torture and cruel, inhumane or degrading treatment.

In detail, general considerations concerning the right to labour that have arisen from the development of international legal instruments will be further explored as China continues to adopt aspects of customary international law and related treaty obligations. UDHR Article 23(1) stipulates that everyone "has the right to work, to free choice of employment, to just and favourable conditions of work and to protection against unemployment", leaving no room for forced labour. Accordingly, any forms of the duty to labour at the international or domestic level, including the Chinese constitutional duty to work, do not include the right to work as established in Article 23(1), as there seems to be no right to free choice of employment or to just and even favourable working conditions. Article 23(2) further declares that everyone "has the right to equal pay for equal work" "without any discrimination." The specific non-discrimination principle generally applies to all workers to fully and effectively protect this right. Article 23(3) requires that workers receive "just and favourable remuneration ensuring for himself and his family an existence worthy of human dignity" to protect the right to fair pay. In addition, Article 24 provides for "the right to rest and leisure, including reasonable limitation of working hours and periodic holidays with pay". Such customary norms appear to classify work-related rights into three groups from a socio-economic perspective: "employment-related rights", "rights derivative of employment as consequential to labour relationships" and those "from an angle of non-discrimination and equality of treatment". The right to free choice of employment falls within the first 
category. The second category primarily includes the right to safe and healthy working conditions, fair remuneration, vocational guidance, training and social security. Finally, the right to non-discrimination or equality of treatment is included in the third category.

Unfortunately, as expected, the subject or content rule seems to be unhelpful in resolving rights conflicts over labour in a predictable manner, although China has been a party to the ICESCR since June 27, 2001. This treaty has also been ratified in China. Similar to the UDHR, the treaty contains a range of labour-related socio-economic rights. These rights also imply the prohibition of forced labour, thereby conflicting with the duty to labour. The rights contained in the ICESCR mainly contain principles concerning non-discrimination and equality, the right to freely chose work, the right to just and favourable conditions of work, rights relating to trade unions and the right to an adequate standard of living and to food and housing (Articles 2; 6; 7; 8, 11). The rights contained in Articles 2(2), 3, 6 and 7 conflict with the requirement of compulsory work as part of the implementation of legal duties under the Chinese Constitution. Accordingly, the prohibition of forced labour under the ICESCR contributes to protecting these rights and implies that this prohibition excludes the duty to labour. Additionally, the above rights are nonderogable under any circumstances as per Article 5(2) of the ICESCR: "no derogation from any of the fundamental human rights recognised or existing in any country in virtue of law, conventions, regulations or custom shall be admitted". Although the ICESCR is limited to economic, social and cultural rights, the principle behind these rights' non-derogable status should apply equally to the right to work as a civil or political right. The principle tends to indicate that if a State has ratified two treaties, the non-derogable principle equally applies to both with respect to resolving conflicts over labour rights.

However, uncertainties persist regarding the conflict over labour rights. Because China signed the ICCPR in 1998 but has not ratified it, China's international obligations appear not to defeat the object and purpose of its constitutional duty to labour from a civil or political perspective. ICCPR Article 8(3) provides for the prohibition of forced or compulsory labour and imposes an absolute and immediate obligation on State parties to prevent it, allowing for a few exceptions to the general prohibition. Article 8(3) guarantees the freedom to labour and obligates State parties to prevent anyone from engaging in practices that limit this right. Article 8(3) is universally applicable to any circumstances concerning forced labour, even where States "extensively regulate the labour market or themselves control it within the scope of a planned economy." While some States, such as China, describe the nature of work (or labour) as both a right and a duty of citizens per the Constitution, the right to work should not in theory or in practice contain provisions establishing a duty to work. "Every general duty to work imposed by State parties that carries a penal sanction" is likely to satisfy the definition of forced labour under Article 8(3)(a). For example, even "the mere lapsing of unemployment assistance when a person refuses to accept work not corresponding to his qualifications" would meet the Article 8(3) (a) definition. Additionally, these requirements of forced labour are important elements that the UN Human Rights Committee, which was replaced by the UN Human Rights Council in June 2006, uses to determine whether facts amount to forced labour for the purpose of a particular case's admissibility, e.g., the dismissed case v. Zambia.

\section{Acknowledgments}

None.

\section{Conflicts of interest}

The authors declare that there are no conflicts of interest.

\section{Funding}

None. 